\title{
THE INFLUENCE OF LOCUS OF CONTROL, SELF-EFFICACY, AND ACCOUNTING ACHIEVEMENT LEARNING ON ACCOUNTING CAREER MATURITY OF THE TWELFTH GRADE STUDENTS OF THE ACCOUNTING PROGRAM IN PRIVATE VOCATIONAL HIGH SCHOOLS
}

\author{
Moh. Danang Bahtiar ${ }^{1}$, Yoyok Soesatyo ${ }^{2}$, Luqman Hakim ${ }^{3}$ \\ Economic Education Program, Universitas Negeri Surabaya \\ danangbahtiar@yahoo.co.id ${ }^{1}$, yoyoksoesatyo@unesa.ac.id ${ }^{2}$, luqmanhakim@unesa.ac.id ${ }^{3}$
}

First draft received: 5 January $2017 \quad$ Final proof received: 28 August 2017

\begin{tabular}{|l} 
First draft received: 5 January 2017 Abstract \\
This study aimed to analyze the influence of locus of control, self-efficacy, and learning achievement in \\
accounting on the career maturity of twelfth grade students of the accounting program in private \\
vocational high schools. The population in the study were twelfth grade students of the Accounting Skills \\
Program at SMK Wachid Hasyim, SMK Kartika 1, SMK and SMK Mahardhika Pawiyatan in the \\
academic year 2015/2016 with a total sample of 175 students. Sampling was conducted using \\
Proportional Sampling Systematic technique. This is descriptive research with quantitative approach, \\
using multiple linear regression analysis. The results showed partially significant influence of the locus \\
of control, self-efficacy, and learning achievements on career maturity of the accounting students, and a \\
simultaneous influence of the locus of control, self-efficacy, and achievement of the twelfth grade \\
students of the accounting Program in private vocational high schools.. \\
Keywords: Locus of control; self-efficacy; learning achievement in accounting; accounting career \\
maturity.
\end{tabular}

\section{INTRODUCTION}

Vocational high school (VHS) is one of the secondary educational institutions whose mission is to prepare middle-level manpower who is skilled and competent in the areas of expertise and projected to fill the jobs in the business and the industries. As part of the national education system, vocational high school has a very important role to address the problems that exist regarding the creation of quality human resources.

Graduates of vocational schools are expected to work immediately after completing their education. However, it turns out in fact that this is not the case. Unemployment rate in East Java Province, for example, until August 2015 showed, the highest rate for VHS graduates, namely $11.74 \%$. Open unemployment rate in both the national and regional levels is largely dominated by vocational school graduates. Fortunately, the government is rigorously promoting vocational high schools in order to create a generation that is ready to work, so as to reduce unemployment.

Seeing the competition is so tight, there is no reason for vocational students to not prepare for their careers as well as possible. That preparation can begin by looking for sources of information about careers and employment through effective exploration process (El Hami, Zahroturrosyida, \& Mariana, 2006), so that when they have to choose a career, they are ready. Such readiness is called career maturity. According to Super (in Seligman, 1994) career maturity is an individual's ability to succeed in overcoming the (life) tasks and transitions in career development and getting ready to choose the right career, according to the age and developmental level. Career maturity includes knowledge of self, knowledge of the work, the ability to choose a job, and the ability to determine the steps towards a career expected (Zulkaida et al., 2012).

Today, there are still many private vocational graduates who do not work in accordance with their educational background. In addition to available jobs that do not fit the number of job seekers, a mismatch between educational background and job types is also the case. This can be seen in institutions, offices, as well as government agencies and private sector vacancies. One of the causes of this mismatch is the 
urgent need to get employed no matter how unsuitable the job is to the academic background.

Field data from a preliminary study done by the researchers show that most vocational high school graduates of the accounting program are able to work according to their educational background. This can be seen from the school data in which $50 \%-60 \%$ of graduates were accepted to work as cashiers, financial staff, bank employees, tax consulting office staff, and employee of public accounting firms. Meanwhile, the preliminary study shows that most of the graduates of private VHS do not work in accordance with their educational background. Data obtained from the school demonstrate that most students prefer to choose the field of administrative work and marketing rather than the accounting field. In average, the number of students who were employed in accordance with accounting expertise was only about $20 \%-30 \%$, while the remaining graduates worked in other areas that did not correspond to educational background. This shows that the maturity level of students' career of private vocational high schools of the accounting program is lower when compared to that of the public vocational high school students.

In achieving the desired career, students face many obstacles, whether originating from within themselves, such as confusion, doubt, and fear to fail in finding a job and or from the outside, such as trusting too much in fate and luck so they tend to surrender and lack efforts in finding a job suitable to their skills. One attempt to overcome these obstacles is to instill locus of control.

Zulkaida et al.'s research (2007) found that locus of control significantly influenced career maturity. In addition, most students still have doubts and fear of failure in carrying out the tasks assigned by the time they work later. Most students are still not sure of the capabilities of doing the task given later. Confidence in the ability of an individual that $\mathrm{s} / \mathrm{he}$ will succeed in doing a task is called self-efficacy. Research conducted by Creed and Patton (2003) on students in Australia have uncovered that one of the factors related to career maturity is self-efficacy.

This is in accordance with the opinion of Bandura (in Zulkaida et al., 2007) that people who have high self-efficacy will expend great efforts to overcome obstacles in achieving their objectives. That is why people who have high self-efficacy will more readily determine which career is right for him.

Learning achievement is one indicator that can be used to measure students' ability to follow the activities of teaching and learning in schools. Outstanding and achieving students are indicated by the values they uphold. Individuals with high academic achievement tend to have extensive knowledge, especially in the subjects concerned and are more able to deal with everyday problems.
Those who have high academic achievement will be able to plan for their future and they have a steady career aspirations. Steady career aspirations will make individuals more serious in seeking information about careers and match their abilities and interests to their future career. They will plan their education and work in the future. Another study conducted by West (2002) states that there is a relationship between career maturity with indian student academic achievement.

Thus, choosing a career is not easy because it takes preparation. Based on the phenomenon as well as the results of several previous studies that have been described above, it is clear that career maturity of accounting students can be influenced by a locus of control, self-efficacy, and achievement in learning accounting. However, most students are not yet ready to determine the direction of their career because there are internal and external obstacles, as well as a lack of confidence with the ability to work in the field of accounting and low learning achievement. Ideally, vocational students of the final grade are ready to determine their career direction according to the development of tasks.

\section{METHOD}

Based on the type of data used, the research is categorized into descriptive research with a quantitative approach. According to Sugiyono (2013) descriptive research is conducted to determine the value of independent variables, either one or more variables, without making comparisons, or connecting it to other variables.

The research intended to get an overview and description of the factors that affect career maturity of the twelfth grade students of private vocational schools of the Accounting program in Surabaya. The research data are presented in the forms of figures and analyzed using statistical data analysis of multiple linear regression to test the hypothesis.

\section{Participants}

The population in this study consisted of 307 twelfth grade students of Accounting program at SMK (Vocational High School) Wachid Hasyim, SMK Kartika 1, and SMK Mahardhika Pawiyatan in the academic year 2015/2016. The research took as many as 175 students as its sample, conducted using Proportional Sampling technique.

\section{Instruments}

The instruments in this research consisted of questionnaire, documentation, and interviews. The questionnaire was used to collect data on locus of control, self-efficacy, and career maturity of the accounting students. The measurement used a Likert scale, with 1-4 alternative answers. Meanwhile, the 
documents as data were in the forms of student achievements (grade reports), lists of students' names, an overview, a brief history and organizational structure of each school and the track record of graduates. Free or unstructured interviews of Master Counseling were carried out to the twelfth grade students and other parties considered having the necessary information related to the aim of the research that would explore the students' understanding of accounting career and the barriers faced in the career.

\section{FINDINGS AND DISCUSSION}

Based on the calculation of research data obtained by multiple linear regression model of:

$Y=48.076+1.069 X_{1}+0.894 X_{2}+0.189 X_{3}+e$ the following results were obtained.

First, a constant value equal to 48.076 was obtained. This means that if the variables of locus of control (x1), self-efficacy (x2), and learning achievement $(\mathrm{X} 3)$ are equal to zero, then the average maturity of Accounting Career $(\mathrm{Y})$ is 48.076 .

Second, b1 regression coefficient value equal to +1.069 was reported. This means that if the variable of locus of control (x1) increases by one unit, then the variable of accounting career maturity will rise by 1.069. A positive sign symbolizes the unidirectional relationship between $X 1$ and $Y$, so that if $X 1$ increases, $Y$ will increase, assuming the other independent variables are zero or constant.

Third, a b2 regression coefficient value equal to +0.894 was gained. This means that if the variable of self-efficacy (X2) increases by one unit, then accounting career maturity will increase by 0.894 . A positive sign symbolizes the unidirectional relationship between $X 2$ and $Y$, so that when $X 2$ increases, $Y$ will increase, assuming the other independent variables are zero or constant.

Fourth, a b3 regression coefficient value equal to +0.189 was obtained. This means that if the variable of achievement $(x 3)$ increases by one unit, then accounting career maturity will increase by 0.189 . A positive sign symbolizes the unidirectional relationship between $X 3$ and $Y$, so that if $X 3$ increases, $Y$ will increase, assuming the other independent variables are zero or constant.

Fifth, $t$-test results show that the $t$ value for locus of control variable was $4.264>t$ table (1.973) and a significance value of $t<0.05$ with a positive regression coefficient. Hence, the first hypothesis that reads "Locus of control has influence on career maturity of accounting of the twelfth grade students of the Accounting program in Private Vocational High Schools" is accepted. This means that the variable of Locus of Control had positive and significant impact on the accounting career maturity of the twelfth grade students of the Accounting program in private vocational high schools. For the self-efficacy variable, $t$ value $4.303>t$ table 1.973 at a significance value of $\mathrm{t}<0.05$, and the regression coefficient has a positive value. So, the second hypothesis that reads "Selfefficacy has influence on accounting career maturity of the twelfth grade students of Accounting program in Private Vocational High Schools" was accepted. This means that the Self-Efficacy variable had positive and significant impact on the accounting career maturity of the twelfth grade students of Accounting program in private vocational high schools.

As for the variable of accounting learning achievement, $t$ value $=2.669>\mathrm{t}$ table $(1.973)$ at $\mathrm{a}$ significance value of $t<0.05$, and the regression coefficient has a positive value; thus, the third hypothesis that reads "Achievement in accounting learning has influence on accounting career maturity of the twelfth grade students of Accounting program in private vocational high schools" was accepted. This proves that the variable of Achievement in Learning Accounting had positive and significant impact on the accounting career maturity of the twelfth grade students of Accounting program in private vocational high schools in Surabaya City.

Based on the results of simultaneous calculations of the influence of Locus of Control, SelfEfficacy, and Achievement in Accounting on Accounting Career Maturity, an $F$ value of 35.766 was reported with a significance value of 0.000 . Because sig. $F<0.05$, the fourth hypothesis that reads "Locus of control, self-efficacy, and learning achievements in accounting simultaneously has influence on accounting career maturity of the twelfth grade students of Accounting program in private vocational high schools" was accepted. This implies that the variables of locus of control, self efficacy, and learning achievements, accounting together had a significant effect on the accounting career maturity of the twelfth grade students of Accounting program in private vocational high schools.

The coefficient of multiple determination (R2) of 0.375 means that $37.5 \%$ of the change in the variable of accounting career maturity of the twelfth grade students of Accounting program in private vocational high schools for the academic year 2015/2016 was influenced by locus of control (X1), self-efficacy (X2), and learning achievement (X3), while the remaining $62.5 \%$ was influenced by factors not included in this study.

From these results, it can be seen that the internal and external locus of control had influence on students' career maturity accounting. This can particularly be seen from the answers to the questionnaire, in which the majority of students agreed to the statement that they have confidence in their abilities and efforts in obtaining a career in accounting. This confidence indicates that the accounting career maturity of the twelfth grade 
students of Accounting Program in private vocational high schools was influenced by the Internal Locus of Control. Furthermore, the internal locus of control of students was in the high category.

As for the sub-variables of external locus of control, it is shown that students also believed that to obtain a career in accounting they needed help from other parties. Additionally, fate and luck affect their obtaining a career in accounting. Thus, it can be concluded that the accounting career maturity of the twelfth grade students of Accounting Program in private vocational high schools was also influenced by the external locus of control, which was included under the medium category. From these results, it can be concluded that sub-variable of internal locus of control was the most dominant, which means students had more confidence in their ability and effort to obtain a career in accounting rather than trusting in others for help or fate or luck.

This result is consistent with the theory put forward by Akbulut (2010) which states that a person mature in a career is likely to have the conviction that to achieve the desired career, can only be done by her/his own efforts and not because of luck, fate or destiny. This means the person who has internal locus of control is more likely to have maturity in determining career, while those who have an external locus of control tend to have less maturity in determining career.

Students who have an internal locus of control will always look for information related to the problem at hand. When confronted with career planning, career exploration, career decision making, knowledge of the job market information, knowledge of the work that attract them, these students will be actively searching for information related to all of it, so that they are expected to have a high career maturity. Furthermore, they will earnestly prepare for their career after finishing school and have a high career maturity.

The results support previous studies conducted by Zulkaida et al. (2007), which suggested that there is a positive relationship between internal locus of control and career maturity. Individuals with an internal locus of control, when faced with a career choice, will make an effort to get to know themselves; find out about employment, educational measures; and try to overcome the problems experienced.

Students who have a high internal locus of control can have a career high maturity. Students who have an internal locus of control believe that events in their life are determined by the business and their own behavior (Friedman \& Schustack, 2009). The same is expressed by Aji (2010) in his research, which showed that the internal locus of control has effect on career maturity. Similarly, the results of research conducted by Hana, Ngadiman, and Hamidi (2013) showed a significant influence of locus of control on job readiness.

Internal locus of control is important to achieve the career maturity of students. By having an internal locus of control in itself is a factor that can help in achieving the maturity of an individual's career. Individuals who have internal locus of control would be active in seeking information about career planning and attempts to acquire knowledge and skill. Therefore, it is important for students to always increase the internal locus of control, so they will be able to increase the maturity of their career.

The results also show that there was significant influence of self-efficacy on accounting career maturity. It can be seen from the statistical analysis of the influence of the variable of self-efficacy on accounting career maturity. The result shows that there was a positive relationship and significant influence, which means self-efficacy could explain the change in accounting students' career maturity.

Furthermore, the results of this study indicate that the majority of students have the confidence to be able to complete the various levels of difficulty of the task in the field of accounting work. It can be seen from the results of questionnaire distribution, in which the majority of students agreed with the statement about the ability to complete various levels of difficulty of the task in the field of accounting work.

In addition, students' beliefs of being capable in completing various levels of difficulty of the task in the field of accounting work can be categorized as very high. This shows that students had very high confidence that they would be able to complete various tasks given job in the accounting field such as being a cashier, treasurer, accounting staff, finance and administration employee, tax employee, etc.. Then, confidence in the students themselves will also be increased when they encounter obstacles in the work. Students also have the confidence to be able to resolve any problems that occur related to the work done in the field of accounting. It can be concluded that the twelfth grade students of the Accounting Program at private vocational high schools in Surabaya City have the confidence and ability in resolving various difficulty levels in the field of accounting, and this confidence will also have an effect on improving students' accounting career maturity.

In terms of the ability for a career in the accounting field, the majority of students agreed that they would be able to pursue a career in accounting. They had a high confidence that with the knowledge and skills they had, they would eventually be able to work in the accounting field like being a cashier, treasurer, accounting staff, clerk and employee of the financial administration, tax administration, etc. This confidence certainly also has an impact on the increase in student's accounting career maturity. It 
can be concluded that the accounting career maturity of students will increase if students have the confidence and ability to pursue a career in accounting. Meanwhile, in terms of the ability to carry out tasks in a variety of accounting jobs, the majority of students gave a statement that they were able to carry out tasks in a variety of accounting work.

This is consistent with the theory put forward by Bandura (in Zulkaida et al., 2007) that people who have high self-efficacy will expend great efforts to overcome obstacles in achieving their objectives. Therefore, students who have high self-efficacy will be better prepared to determine which career is right for them according to their ability, knowledge and skills. The results also support previous research results conducted by Betz (2004) which showed that there is a positive relationship between self-efficacy and career maturity. Low levels of self-efficacy are associated with less likelihood of someone to consider several options pertaining to his career.

Furthermore, Creed and Patton (2003) uncovered that one of the factors related to career maturity is self-efficacy. Seligman in Komandyahrini and Hawadi (2008) stated that one of the characteristics of career maturity level is marked by the increasing positive attitude associated with the self-efficacy of career maturity.

Komandyahrini and Hawadi (2008) further argued that students who have high self-efficacy will love the challenge that show interest and involvement in an activity, improve business when performance has failed to achieve the desired goals, look for the cause of the failure, not experience anxiety in performing tasks, and have low stress. Therefore, it is important for students to always improve their selfefficacy in planning and selectin careers according to their ability, skills, and knowledge, so they will be able to increase their career maturity.

The results also showed a significant influence of learning achievement on accounting career maturity of the twelfth grade students of the Accounting program in the city of Surabaya in the academic year $2015 / 2016$. It can be seen from the results of statistical analysis of data on the correlation between achievement in accounting and accounting maturity career. It was reported that there was a positive relationship with significant influence, meaning that accounting learning achievement could explain the change in students' accounting career maturity.

This finding is consistent with the theory put forward by Farmer (in Seligman, 1994), who explained that learning achievement has implications for the development of one's career. Students who have a greater learning achievement in school is likely to be easier to plan his career carefully, while students who have low learning achievement in school is likely to experience difficulties in planning his career. Lower educational achievement will limit the ability of students in determining career planning due to the inability to adjust to the requirements or criteria required.

The results support previous research conducted by Creed and Patton (2003) who reported that learning achievement is one important factor in career maturity. Syahrul and Jamaluddin (2007) also reported that students who have great learning achievement are able to see far ahead; they have aspirations of work; and therefore they will plan the type and level of education to take and complete. Similarly, the results of research conducted by the West (2002) revealed that there is a relationship between career maturity and academic achievement in students. In addition, the results of research conducted by Dhillon and Kaur (2005) showed that the variables that influence students' career maturity include self-concept, motivation, and learning achievement.

Based on these results it can be concluded that the students' learning achievement in accounting had influence on their accounting career maturity, which means that the better the grades obtained by the students on the subjects of vocational competence of accounting, the more improve their career maturity in accounting will be. This is because students with high learning achievement in accounting will be better able to master a wide range of science-related accounting subjects so that later they will be better prepared to choose a career or a job in the accounting field. This so, especially compared to students who have low learning achievement in accounting subjects; they will tend to be reluctant to choose a career or a job in the accounting field because they feel they lack the ability in that field.

Given the importance of learning achievement in accounting in improving career maturity of accounting students, then teachers as a mediator in the learning process should always provide encouragement and motivation to students to always learn seriously and strive to improve their academic achievement in school so that later they can make a careful career planning in accordance with the field of science they have learned at school.

Based on the analysis of statistical data in this study, it is indicated that locus of control, self-efficacy self, and learning achievement in accounting simultaneously influenced career maturity of the twelfth grade accounting program students of private vocational high schools. This is further translated as locus of control, self-efficacy, and learning achievement in accounting could simultaneously explain the change in the career maturity of the students.

This result is consistent with the results of research conducted by Septirini (2014) which reported that there internal locus of control, external 
locus of control, self-efficacy and learning achievement simultaneously had influence on career maturity of the twelfth grade accounting program students of SMK Maarif NU 1 Cilongok, academic year 2013/2014.

Therefore, it can be concluded that locus of control, self-efficacy, and achievement in accounting contributed to the accounting career maturity of the students in this research. To be able to increase the maturity of accounting career, it is necessary to increase locus of control, especially the internal one because increased internal locus of control will make students have the drive or motivation to attempt to obtain a career in accounting in accordance with their ability and effort without relying on or trust in fate, destiny, and help from others. Besides, accounting career maturity may increase if students have high self-efficacy, meaning that they have the confidence to be able to complete the various levels of difficulty of task in the field of accounting work, are capable of a career in accounting, and are able to carry out tasks in various jobs in the accounting field.

The learning achievement acquired by accounting students also has influence on the increase of their career maturity. Students who have a high learning achievement in accounting will be better able to master a wide range of science-related accounting subjects so that later they will be better prepared to choose a career or a job in the accounting field.

Therefore, students, teachers, parents, and communities should be able to know about the importance of the factors that influence accounting career maturity to help students make career planning in accounting carefully before entering employment, so that later after completing their study, they can directly be absorbed by employment in accordance with their expertise.

This is certainly in accordance with the mission to prepare a skilled vocational manpower that is also competent in the areas of expertise that are projected to fill the jobs in the employment and industries. So that it is expected that vocational graduates, primarily those of accounting program, will be absorbed by the job market and will ultimately have an impact on reducing the rate of unemployment in Indonesia.

\section{CONCLUSION}

Based on the results of research and data analysis, the conclusion can be stated as follows: locus of control had significant influence on and a positive relationship to accounting career maturity of the twelfth grade students of the accounting program in private vocational high schools. This proves that both internal and external locus of control are the driving factor that can improve students' career maturity in accounting.
Self-efficacy also had significant influence on and a positive relationship to accounting career maturity of the students. Students who have high selfefficacy will have increased maturity in their accounting careers. This proves that self-efficacy is the driving factor that can improve students' career maturity in accounting.

Finally, learning achievement has significant influence on and a positive relationship to accounting career maturity of the students. Students who have high learning achievement in accounting will have increased maturity in accounting careers. This proves that accounting students' learning achievement is the driving factor that can improve students' career maturity in accounting.

\section{REFERENCES}

Aji, R. (2010). Hubungan antara internal locus of control dengan kematangan karir pada siswa kelas XII SMK N 4 Purworejo. (Unpublished Thesis). Universitas Diponegoro, Indonesia.

Akbulut, N. (2010). The relationship between vocational maturity and hopelessness among female and male twelfth grade students. (Unpublished Thesis). Middle East Technical University, Turkey.

Bandura, A. (1997). Self-efficacy: The exercise of control. New York: W. H. Freedman and Company.

Betz, N. E. (2004). Contributions of Self Efficacy theory to Career Counseling: A Personal Perspective. Career Development Quarterly, 52, 340-353.

Creed, P. A., \& Patton, W. (2003). Predicting two components of career maturity in school based adolescents. Journal of Career Development, 29, 277-290.

Dillon, U., \& Kaur, R. (2005). Career Maturity of School Children. Journal of the Indian Academy of Aplied Psychology, 31, (1-2), 7176.

El Hami A., Zahroturrosyida H., \& Mariana, S. (2006). Gambaran kematangan karir pada para calon sarjana di lingkungan Fakultas Psikologi Universitas Padjajaran. Research Report, 135.

Friedman, H. S., \& Schustack, M. W. (2009). Kepribadian: Teori klasik dan riset modern. Jakarta: Erlangga.

Hana, B. M., Ngadiman, \& Hamidi, N. (2013). Pengaruh pengalaman praktik kerja industri (Prakerin) dan locus of control terhadap kesiapan kerja siswa kelas XII SMK Negeri 1 Surakarta. JUPE, 1(1), 1-11.

Komandyahrini, E., \& Hawadi, L. F. (2008). Hubungan self-efficacy dan kematangan dalam memilih karir siswa program percepatan belajar. Jurnal Keberbakatan \& Kreativitas, 2(1), n.p.

Seligman, L. (1994). Developmental career counseling and assessment. Thousand Oaks: Sage Publications. 
Septirini, A. T. (2014). Pengaruh locus of control, efikasi diri dan prestasi belajar terhadap kematangan karir siswa XII Akuntansi SMK Ma'arif NU 1 Cilongok. (Unpublished Undergraduate Thesis). Universitas Negeri Semarang, Indonesia.

Sugiyono. (2013). Metode Penelitian Pendidikan (Pendekatan Kuantitatif, kualitatif Dan R\&D. Bandung: CV Alfabeta.

Syahrul \& Jamaluddin. (2007). Kematangan vokasional mahasiswa program D-3 Jurusan Teknik Mesin Fakultas Teknik Universitas Negeri Makassar. Jurnal PTM, 7(1), n.p.

West, D. K. (2002). Comparisons of Career Maturity and Its Relationship with Academic Performance. Journal of American Indian Education Vol. 27, No. 3 pp. 1-7.

Zulkaida, A., Kurniati, T. N. M., Rentaningsih, \& Muluk, H. (2012). Pengaruh locus of control dan efikasi diri terhadap kematangan karir sekolah menengah atas (SMA). Jurnal Proceeding PESAT, 21-22. 